\title{
RESPONSE
}

\section{Do Witches Exhume Dead Bodies?}

\author{
Esther Mombo
}

"Why are we having only two weeks of vigil for your mother, for your father we had one month."

Life after death, or the afterlife, is a subject of interest in most religious traditions in many societies. Writing about African Traditional Religious beliefs Mbiti observed that "in many ways the hereafter is a carbon copy of the present because personalities are retained, social and political status are maintained, sex distinctions are continued human activities are reproduced and the wealth or poverty of a person remains unchanged"(Mbiti 1969, 161). As well as this, the fears of the people about witchcraft also remain the same. In real life people fear witchcraft and witches, at death the people fear that witches will exhume the dead body and use it for ritual purposes.

This is in line with the definition of witches as observed by Wehmeier and Ashby, who define witchcraft as "the use of magic powers, especially evil ones" (2000, 1371). The concept, witchcraft, therefore refers to the use by some people of evil magic powers to harm or cause misfortune to others. Witchcraft is therefore regarded as ". . . the supposed power of a person to harm others by occult or supernatural means, without necessarily being aware of it" (ibid). Kritzinger (2004, 180) describes the African witch in almost similar terms: In Africa, witches are always viewed as evil, and are not always female. In many African countries, it is believed that witchcraft runs in the family and that one is born a witch. Witches are believed to have a natural inclination to carry out evil, making people ill and even causing death. After death in some communities they are believed to exhume the bodies to use them for ritual practices, for example among the Abagusi, my own group. I will tell my own story:

My father died thirty years ago and we were young and could only depend on our relatives to plan and conduct the funeral. While as children we would have asked to do things differently we were not allowed. His grave was dug in front of the house as is custom and built with cement at the bottom. The coffin was covered with iron sheet and a metal before the grave was covered. There was a vigil for one month from 6pm to 6am in the morning. The vigil was done by both men and women taking turns each night to come and stay. My mother and the women had a vigil spot and my uncles and other village men had their spot. In the morning they shared experiences of the vigil. I did not participate in the vigils as I had to go back to my school the same as my brothers and sister. When I returned to visit my mother, I heard stories about the vigils and how committed the team was to make sure that the witches did not get my father. After one month they would not bother.

In November this year my mother died and, unlike my father's funeral, as siblings we had time to plan our mother's funeral and to execute it. With the support of the church and the larger community, all aspects of the burial were adhered to, for instance the preparation of the grave. With fear of witches exhuming the body, the grave was dug to a depth of seven feet, it was cemented inside, it was covered by an iron sheet, before filling the grave with the soil. My mother's funeral went well and we were happy that we had given our mother a good send off. After the funeral of my mother, and when the crowds had left, family and close relatives stayed behind as is custom. My brothers and sisters shared with each other when they were to depart as most of us work away from home.

Two of my siblings said they would be home for two weeks because they had taken leave. Immediately one of my relatives asked why we were not staying longer to hold vigils for my mother. Were we not aware of witches exhuming bodies? My relative went on at length to explain how the bodies are exhumed and taken away to be used by witches for witchcraft. While my mother was ailing occasionally we were asked if we had checked with the African healers as much as we were using hospital medicine to treat her. We did not venture to follow up on the discussion about checking if my mother was bewitched. For some people they would exclaim that whoever sent this disease to my mother would also suffer, God will repay him or her. During the funeral no one spoke publicly about witchcraft, so I was surprised that we were being told to keep a vigil and look after my mother's grave in case the witches take her body. 
A number of things could be deduced from the discussion about keeping my mother's vigil. Even though there have been thirty years between my father's funeral and my mother's funeral, the beliefs and worldview about witches has not changed. In a newspaper report a journalist observed that "Kisii is infamous for witches, real or imagined. And none strike as much terror as those said to prowl graveyards in the dead of the night, and falling upon fresh graves to dig up decomposing corpses. They eat them, so goes legend. The very thought of a loved one's body getting exhumed and eaten sends a cold shiver down the spine of many among the Abagusï" (Nairobian 2019). These are the fears that gripped my relative in raising the matter of the vigil with us.

Along with the time difference in the period of the two funerals, the church members oscillate between the two worldviews even in the current time: the world of the existence of witches which is deep and the world of not taking note of them on the surface. The reality is that, in cases of life and death when there are no answers, there is a comfort in bringing the witches into the picture and not ignoring their existence or the power they hold. The general view of the church as an institution may be that the stories about witches are mere imaginations, but individuals take the stories seriously when they are directly affected.

What is the connection between this and the report about child witches in the Congo (Priest, Ngolo and Stabell 2020)? In most of the stories about the children accused of witchcraft, the child has a sad background, of not being wanted. To culminate the hatred the child is accused of being a witch. The child in the first place is a burden to the family, and to get rid of the child they accuse them of witchcraft which is emotive and people believe it.

Not until we explain and respond to the questions that arise at the times of death, will the fears of witches cease to be part of our worldview. Likewise, until we sort out issues of unwanted children like in the Congo, compounded by poverty, children will continue to be accused of witchcraft to enable families to get rid of them. I have two points with which to conclude: First, the ministry of exorcism that the church seems to have undertaken is a difficult one, and second witchcraft is not the real issue-the real issue is how we deal with a patriarchal society where children who do not fit a family setting as a result of broken marriage or the death of one parent. So witchcraft is not the real problem, but it is a peg on which the questions of life are hung.

\section{References}

Mbiti John. 1969. African Traditional Religions and Philosophy. Nairobi Heinemann.

Wehmeier Sally and Michael Ashby. 2000. Oxford Advanced Learner's Dictionary. Sixth Edition.

Kritzinger, Johannes Nicolaas Jacobus. 2000. Exploring Theology: An Introductory Dictionary. Pretoria: Research Institute for Theology and Religion, University of South Africa.

Nairobian. 2019. Kisii: Where Witches Hunt for 'Dead Meat' in Graves.

https://www.sde.co.ke/thenairobian/article/2001279973/ (Accessed on 18.12.2019)

Priest, Robert J., Abel Ngolo and Timothy Stabell. 2020. Christian Pastors and Alleged Child Witches in Kinshasa, DRC. On Knowing Humanity Journal 4(1):1-51.

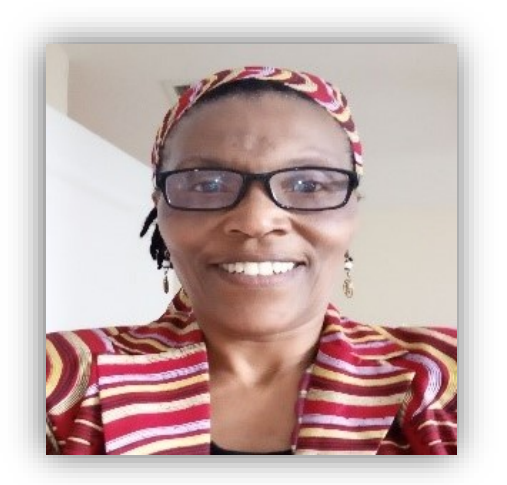

Esther Mombo is at St. Paul's University Limuru, where she is Director of Partnerships and Alumni Relations, and Lecturer in the Faculty of Theology in the same university, Department of History. Her research interests include women, church, theological education and the ministry of the church.

Author email: esthermombo@vahoo.co.uk 